\title{
A magyar mikro-, kis- és középvállalatok versenyképessége és pénzügyi teljesítménye
}

A tanulmány a mikro-, kis- és középvállalati szektor vállalatainak kompetenciateljesítménye alapján értelmezett versenyképesség és pénzügyi teljesítmény közötti kapcsolatot vizsgálja. Az összefüggés megteremtésén túlmenően azt is elemzi - ellentétben a teljesítményt alakító mechanizmusok elemzésével foglalkozó más tanulmányokkal -, hogy a mikro-, kis- és középvállalatok hogyan használják fel megtermelt profitjaikat. Az elméleti megalapozást, modellalkotást és hipotézisalkotást követően az empirikus kutatási eredmények bemutatására kerül sor. Az 1005 magyar mikro-, kis- és középvállalat vizsgálata regresszióelemzéssel történt. Az eredmények azt mutatják, hogy 1 . mind a jövőbe, mind a múltba irányuló pénzáramlások meghatározók a versenyképesség kialakításában. Ezen belül 2. elsősorban az innovációnak és az osztalékfizetési képességnek van szignifikáns hatása, miközben 3. az állóeszköz-beruházás hatása ellentmondásos. A tanulmány újdonságát a mikro-, kis- és középvállalatok versenyképessége és pénzügyi teljesítménye közötti kapcsolat modellezése és empirikus elemzése adja. Ezek a tudományos fóáram szakirodalmai alapján hiánypótlónak tekinthetők.

Journal of Economic Literature (JEL) kód: G39, L26.

Az elmúlt évtizedekben a versenyképesség is (Buckley és szerzőtársai [1988], Wach [2014]) és a pénzügyi teljesítmény is (Kaplan-Norton [1996], Chatfield-Vangermeersch [2014]) népszerü vizsgálati témákká váltak a tudományos fóáramban, tanulmányok egyaránt foglalkoznak a nagyvállalatokkal és a mikro-, kis- és középvállalatokkal. Mindazonáltal a két kutatási terület közös metszetében alig találhatók empirikus

* A kutatás, amelyet az Innovációs és Technológiai Minisztérium Felsőoktatási Intézményi Kiválósági Programja finanszírozott, a Pécsi Tudományegyetem 4. - A hazai vállalatok szerepének növelése a nemzet újraiparosításában - tématerületi programja keretében zajlott. A tanulmány az Innovációs és Technológiai Minisztérium - ÚNKP-20-4 kódszámú Új Nemzeti Kiválóság Programjának a Nemzeti Kutatási, Fejlesztési és Innovációs Alapból finanszírozott - szakmai támogatásával készült.

Márkus Gábor közgazdász, a Pécsi Tudományegyetem Közgazdaságtudományi Kar Pénzügy és Számvitel Intézet adjunktusa (e-mail: markus.gabor@ktk.pte.hu).

Rideg András közgazdász, a Pécsi Tudományegyetem Közgazdaságtudományi Kar Kvantitatív Menedzsment Intézet adjunktusa (e-mail: ridega@ktk.pte.hu).

A kézirat első változata 2020. augusztus 13-án érkezett szerkesztőségünkbe.

DOI: http://dx.doi.org/10.18414/KSZ.2021.6.617 
elemzések: a versenyképesség területén főként a versenyelőnyök és azok meghatározó tényezöi (Porter [1990], Krugman [1994], Barney [1991], [2001]), a pénzügyi teljesítmény mérése területén pedig leginkább a tőzsdén jegyzett vállalatok uralják a kutatási érdeklődést (Rappaport [1997], Damodaran [2002]).

A versenyképességi kutatásoknak inkább a vállalati szintü kompetencia mérését (Grant [1991], [2016]), valamint a kompetencia és a pénzügyi teljesítmény közötti összefüggések elemzését (Szerb és szerzötársai [2014] és [2019]) kellene célul kitűzniük, azaz azt kellene vizsgálniuk, hogy melyek a hosszú távú sikerhez szükséges alapvető kompetenciák.

A kompetenciaalapú versenyképesség és a pénzügyi teljesítmény közötti kapcsolat egyike a legkevésbé vizsgált kutatási területeknek (Chatfield-Vangermeersch [2014]). A pénzügyi teljesítmény elemzései döntően az Egyesült Âllamok tőzsdén jegyzett társaságaira koncentrálnak (Brem és szerzőtársai [2008]), egyrészt a cash flow generálási képességekkel (Greenberg és szerzőtársai [1986]), másrészt a részvényárakkal összefüggésben (Damodaran [2002]). Ezek mellett a mikro-, kis- és középvállalati szektor vállalatainak pénzügyi teljesítményét vizsgáló tanulmányok alig jelennek meg a szakirodalomban, ha pedig mégis, akkor elsősorban a hitelképességgel kapcsolatos kérdésekre összpontosítva (Berger-Udell [2006]).

A leírtak alapján az alábbi három területen azonosítható kutatási rés: 1 . Hogyan kapcsolódik össze a versenyképesség és a pénzügyi teljesítmény a mikro-, kis- és középvállalati szektorban? 2. Miután a mikro-, kis- és középvállalatok a magas versenyképességet és a pénzügyi sikert elérték, hogyan költik el a forrásaikat? 3. Learatják-e sikereik gyümölcsét, és kivonják-e a profitot a vállalkozásból, vagy további beruházásokat hajtanak végre a vállalkozás jövője érdekében?

A mikro-, kis- és középvállalati szektor kompetenciateljesítmény mérésén alapuló versenyképesség-vizsgálatai során tettek már kísérletet a pénzügyi teljesítmény figyelembevételére (például Szerb és szerzőtársai [2014] és [2019]), ám a módszer végső változatából ezt a nézőpontot kihagyták. Indoklásuk szerint az expost pénzügyi-számviteli adatokra alapozott a pénzügyi mérőszámok nem okoznak teljesítményt, „csak” az elért teljesítményt reprezentálják. Összességében fontos lenne a teljesítményt kiváltó és a teljesítményt reprezentáló tényezők közötti kapcsolatot megérteni és a tudományos ismereteket empirikus eredményekkel bővíteni.

Jelen kutatás célja az, hogy megvizsgálja a mikro-, kis- és középvállalatok kompetenciateljesítménye (versenyképessége) és pénzügyi teljesítménye közötti kapcsolatot. A kompetenciákat leíró vállalati szintủ adatok a Pécsi Tudományegyetem Közgazdaságtudományi Karán müködö Mikro-, Kis- és Középvállalati Versenyképesség Kutatóközpont (KKVVKK) 2020. május 20-i dátumbélyegü magyar adatállományából származnak, a pénzügyi adatok pedig nyilvánosan hozzáférhető adatgyüjteményből.

A tanulmány az alábbi felépítést követi: a téma szakirodalmának áttekintését követő módszertani részben felépítjük a kutatás alapmodelljét és felállítjuk hipotéziseinket, valamint ismertetjük a kompetenciateljesítmény és a pénzügyi teljesítmény mérési eljárásainak részleteit. Ezt követően elemzésünk eredményeit mutatjuk be. Végül következtetéseink során ismertetjük az eredmények szakmai narratíváját, elméleti és gyakorlati alkalmazhatóságát, a kutatás korlátait és a további kutatási irányokat. 


\section{Szakirodalmi áttekintés}

\section{A mikro-, kis- és középvállalatok versenyképessége}

A versenyképességet vizsgálták már definitív eszközökkel, teoretikus módon és empirikus kutatásokban is - termék-, üzletági, vállalati, iparági, regionális, nemzeti és szupranacionális szinten egyaránt (Delgado és szerzőtársai [2012], Wang [2014]). Továbbá számos irodalomszintetizáló cikk és metaelemzés (Buckley és szerzötársai [1988], Stojcic [2012], Wach [2014]) is megjelent már. Ugyanakkor - a szintek keveredésén túl - többen bírálták már a versenyképesség különböző felfogásait is, a homályos, túl széles körü vagy tartalmatlanul rövid definíciókat, különösen az egyes versenyképességi tényezők politikai eszközökkel történő befolyásolását illetően (Bristow [2010], Krugman [1994], Porter [1990]). Hasonló kritikákat fogalmaztak meg a versenyképesség mérésének szakirodalmáról az elméleti megalapozottság hiánya, a tényezök öncélú, ad hoc megválasztása és a homályos metódusok alkalmazása miatt (Huggins-Thompson [2013], Lall [2001]). A tudományos ismeretanyag konzisztenciájának hiánya arra enged következtetni, hogy a versenyképesség kutatása napjainkban és a közeljövőben is releváns téma marad. A viták pedig hozzájárulnak ahhoz, hogy a versenyképesség elméleti és gyakorlati irányú fejlesztése folytatódjon (Delgado és szerzőtársai [2012]).

Michael Porter munkája úttörő szerepet játszott a vállalatok versenyképességének megértésében. Porter [1990], [1998] szerint a magas és növekvő termelékenység a vállalatok piaci sikerének kulcsa. Ezzel a termelékenység áll a porteri versenyképességi megközelítés központjában, amelynek szintjét az egységnyi inputra jutó reálkibocsátással értelmezi. Véleménye szerint a vállalatok versenyképessége (termelékenysége) egyaránt függ a makrogazdasági és a mikrogazdasági versenyképességtől, valamint az adottságoktól. A mikrogazdasági versenyképességet az üzleti környezet minősége, a klaszterfejlesztés állapota, valamint a vállalati működés és a stratégia kifinomultsága befolyásolja. A makrogazdasági versenyképességre a költségvetési és monetáris politika, a gazdaság stabilitása, valamint az emberi erőforrások fejlesztése és a hatékony politikai intézmények gyakorolnak hatást. Az ország adottságai (például természeti erőforrások, földrajzi elhelyezkedés, a népesség nagysága, az ország mérete) megteremt(het)ik a jólét alapját, de valós prosperitás az adottságok termelékeny kihasználásából fakad (Delgado és szerzőtársai [2012] 9-14. o.).

Kutatásunkban döntő szerepe van a Szerb és szerzötársai [2014] és [2019] által kifejlesztett, a vállalati szintü kompetenciák teljesítményének értékelésén alapuló mikro-, kis- és középvállalati versenyképesség-felfogásnak és -módszertannak, ezért ezek bemutatása és a kapcsolódó alapfogalmak tisztázása elengedhetetlen. Idézzük az általános vállalati versenyképesség fogalmának meghatározását:

„A vállalati versenyképesség felfogásunkban a vállalatnak azon képessége, hogy a társadalmi felelősség normáinak betartása mellett tartósan tud olyan termékeket és szolgáltatásokat kínálni a fogyasztóknak, amelyeket azok a versenytársak termékeinél inkább hajlandók a vállalat számára nyereséget biztosító feltételek mellett megfizetni. E versenyképesség feltétele, hogy a vállalat legyen képes a környezeti és a vállalaton belüli változások 
érzékelésére és az ezekhez való alkalmazkodásra a versenytársainál tartósan kedvezőbb piaci versenykritériumok teljesítésével." (Chikán [2008] 24-25. o.)

A definíció a nemzetközi szakirodalomban is széles körben ismert és alkalmazott (például Lee-Karpova [2018]). Chikán [2008] meghatározása a társadalmi felelösségi normák betartásának hangsúlyozásával a vállalatokat egy komplex gazdasági-társadalmi kontextusban működőnek írja le, ezeket társadalmi képződményeknek is tekinti. Kiemeli továbbá a kettős értékteremtés fontosságát azzal, hogy a tulajdonosok és a fogyasztók előtti megfelelés követelményeit egyaránt megfogalmazza. Kifejti azt is, hogy a versenyképesség a piaci verseny feltételei mellett értelmezhető, amelyben a vállalatok termékeikkel vesznek részt. A termékpiacokon keresztül azonosítják a versenytársakat, amelyek a működést befolyásoló külső - környezeti - hatásokhoz való alkalmazkodás során a viszonyítási alapot jelentik. A fogalom hasznosítható a gazdálkodástani tudományágon belül valamennyi funkcionális üzleti terület számára, továbbá lehetőséget biztosít a versenyképesség többszintű elemzésére. A Chikán-féle általános vállalati versenyképesség definíciót Szerb és szerzőtársai [2014] és [2019] egy indexkészítést lehetővé tevő koncepcionális modellhez igazították abból a célból, hogy a mikro-, kis- és középvállalatok kompetenciaalapú versenyképessége mérhetö legyen.

Szerb és szerzőtársai [2014] és [2019] elsősorban a stratégiai menedzsment és a kis- és középvállalt-specifikus üzleti ismeretek szakirodalmából merített (AragónSánchez-Sánchez-Marín [2005], Dholakia-Kshetri [2004], Grant [1991], LengnickHall [1992], Man és szerzőtársai [2002], McGahan [1999], Peteraf [1993], Ray és szerzőtársai [2004], Singh és szerzötársai [2007], Vecsenyi [2011]). Ezen források hangsúlyozzák azt, hogy a kisvállalatok fokozottan ki vannak téve a környezeti és piaci változásoknak, a belső és külső erőforrások korlátozottan állnak rendelkezésre, valamint a kis méretből fakadó hátrányok ellensúlyozására a nagyvállalatoknál jobban kényszerülnek együttmüködésre külső partnerekkel. A hátrányokat a kisvállalatok egyszerübb vállalati struktúrával, nagyobb flexibilitással és gyorsabb válaszreakciókkal kompenzálhatják. A koncepcionális modell kialakítása során hasznosították továbbá a Miller-féle konfigurációs elméletet (Miller [1986], Miller-Whitney [1999]), amely szerint a versenyképesség tényezői összefüggnek és rendszert alkotnak a vállalatban. A vállalati szintű kompetenciák teljesítményének elemzései illeszkednek továbbá a versenyelőnyök erőforrás-alapú elméleteihez is (például Wernerfelt [1984], Barney [1991], [2001]). A kutatók összességében egyetértenek abban, hogy a vállalatok versenyképességét számos tényező alakítja, de vitáznak arról, hogy pontosan mely tényezők és milyen mértékben határozzák meg.

A KKVVKK kutatói a fentiekben bemutatott keretek között határozták meg azon szakirodalmi művek körét, amelyek alapul szolgáltak a mikro-, kis- és középvállalati versenyképesség - kutatásaik során alkalmazott - definíciójának megalkotásához:

„Egy KKV versenyképessége a vállalat alábbi jellemzőinek és egymással szoros kapcsolatban álló, rendszert alkotó belső vállalati kompetenciáinak együttese: hazai piac, együttműködés, nemzetköziesedés, humán tőke, kínált termék/szolgáltatás, termelés, értékesítési mód (marketing), online jelenlét, döntéshozatal, stratégia. Ezek teszik lehetővé 
a vállalat számára azt, hogy hatékonyan versenyezzen más vállalatokkal, és olyan termékeket/szolgáltatásokat nyújtson, amelyeket a fogyasztók magasra értékelnek." (Szerb és szerzötársai ([2019] 32. o.)

A mikro-, kis- és középvállalati versenyképesség szisztematikus kutatását különösen relevánssá teszi az, hogy a tudományos kutatások jellemzően a cégeknek csak egy bizonyos körét, általában a magas növekedési potenciálú, munkahelyeket magas számban teremtő, „gazella” jellegű vállalatokat vizsgálják (Acs [2011], Henrekson-Johansson [2010]). Ezzel azonban a gazdaságban legnagyobb számban előforduló cégekről és a versenyképességüket alkotó tényezőkről a tudásunk korlátozott marad. Szisztematikus vizsgálatok nélkül azt sem tudjuk, hogy pontosan milyen gazdaságpolitikai-szakpolitikai intézkedésekkel is lehetne a mikro-, kis- és középvállalatok versenyképességét javítani. Ráadásul a kisebb méretü cégek tulajdonosai, vezetői, alkalmazottai, a vállalati müködés érintettjei (stakeholders) sem kapnak kellö információt a vállalat versenyképességének valós állapotáról, illetve arról, hogy mit is kellene tenni az adott cég képességeinek, eredményeinek javítása érdekében. A kisvállalati körben egyébként is gyakori a saját eredmények túlértékelése, a valós helyzetnél jobb versenyképességi állapot véleményezése. A leírtakat figyelembe véve a versenyképesség és a pénzügyi teljesítmény közötti kapcsolat elemzése mind a tudományos ismeretek bővítése, mind az üzleti élet gyakorlata szempontjából lényeges.

\section{A mikro-, kis-és középvállalatok pénzügyi teljesítménye}

Számos, a vállalatok pénzügyi döntéseivel foglalkozó elméleti modell létezik, mint például a tökeszerkezet hierarchiaelmélete (pecking order theory) (Myers-Majluf [1984]), az osztalékpolitika-elmélet (dividend policy theory) (Miller-Modigliani [1961]) vagy a megbízó-ügynök-elmélet (agency cost-based theory) (Jensen-Meckling [1976]). A tőkeszerkezet hierarchiaelmélete arra hívja fel a figyelmet, hogy a vállalatok az új tőke bevonása során meghatározott sorrendet (hierarchiát) követnek. Az osztalékpolitikaelmélet a vállalat értékének növelése szempontjából a jövőbeli cash flow-k jelentőségét hangsúlyozza. A megbízó-ügynök-elmélet azt hangsúlyozza, hogy a vállalatok vezetői önérdekkövető magatartást követve hajlamosak nem hatékony projektek (a kelleténél magasabb kockázat és/vagy alacsonyabb nyereségesség melletti) megvalósítására is. Ezek az elméletek azonban azt vizsgálják, hogy a vállalkozások hogyan keresik meg a pénzt, és alig mondanak valamit arról, hogy mire költik.

Számos nehézségbe ütközünk, amikor a hivatkozott elméleteket a mikro-, kis- és középvállalati szektorra próbáljuk alkalmazni. A hierarchiaelmélet feltételezi, hogy a vállalatnak lehetősége van megválasztani a tőkeszerkezetét, holott minél kisebb egy vállalkozás, annál kevésbé van erre módja. Az osztalékpolitika oldaláról nézve fel kell ismernünk, hogy egy kisvállalkozás tulajdonos menedzserének számos lehetősége van arra, hogy a vállalkozása által generált cash flow-t kisajátítsa, az osztalék csak egy ezek közül a lehetőségek közül. A megbízó-ügynök-elmélet az információs aszimmetriát hangsúlyozza két oldalról is. Egyrészről, ha a vállalkozás belső 
működését vizsgáljuk, akkor fel kell ismernünk, hogy a mikro-, kis- és középvállalatok esetében a tulajdonos és a menedzser az esetek nagy részében ugyanaz a személy, aki ráadásul erős, közvetlen befolyással rendelkezik a vállalkozás folyamataira, és ez automatikusan csökkenti az információs aszimmetriát és így az ügynöki költségeket is. Másrészről, amikor az említett vállalkozás valamilyen külső finanszírozóval kerül kapcsolatba, az információs aszimmetria megfordul: a vállalkozás tulajdonos menedzserének mindig is több információja lesz a müködésről. Ez az aszimmetria szinte magától vezet oda, hogy a jövedelmeket túl-, míg a kockázatokat alulbecsülik, ami növeli az ügynöki költségeket (Berger-Udell [1998]) és a nem hatékony projektválasztást (Berger-Udell [2006]).

Az innovációnak a gazdasági fejlödésben betöltött jelentőségét Schumpeter [1976], [1980] kutatása óta már jól ismerték. Schumpeter szerint a vállalkozói innováció gazdasági átalakuláshoz, új termékek és új technológiák létrehozásához, új piacok és alapanyagforrások felfedezéséhez és új szervezeti megoldások alkalmazásához vezet. A vállalati szintű kutatásokat végző kutatók úgy találták, hogy az innovációs tevékenység végrehajtását a nagyvállalatok részesítik előnyben az erőforrás-mennyiség, a tudás, a tudományos módszerek és a külső feltételek ellenőrzése terén, míg a mikro-, kis- és középvállalatok az ötletekre, a motivációra és a szervezeti szintű rugalmasságra koncentrálnak (például Nooteboom [1994], Vossen [1998]).

Az innováció, a nemzetköziesedés és a vállalati teljesítmény különböző elemei széles körben vizsgált témák az irodalomban. Belderbos és szerzőtársai [2013] arra a tényre hívta fel a figyelmet, hogy még a fejlödő országokban müködő kisvállalkozások is nagy hatással lehetnek a nemzetközi innovációs irányokra. Az erőforrás-alapú elmélet és a folyamatalapú nemzetközivé válás elmélete alapján Arslanagic-Kalajdzic és szerzőtársai [2017] a termékinnováció és az exporttevékenységek kapcsolatát vizsgálta, és arra a következtetésre jutott, hogy a tényezők között $U$ alakú kapcsolat van: a cégeknek fokozniuk kell az innovációs képességeket, mielőtt belépnének a nemzetközi piacokra. Makroszempontból Filippetti és szerzötársai [2017] alapján a gazdaság abszorpciós képessége alapvető szerepet játszik az innováció elterjedésében: a magas abszorpciós képességű országok jobban profitálnak a folyamatból, míg az alacsony abszorpciós képességü országokban az importált innovációk kiszorítják a helyi kezdeményezéseket. Halilem és szerzötársai [2014] ezt közelebbi és tágabb piacok bevezetésével bővítte ki. Egyrészt Filippetti és szerzőtársai [2011] hangsúlyozta, hogy oda-vissza ható kapcsolat van az innováció és a nemzetköziesedés között, másrészről Halilem és szerzőtársai [2014] arra a következtetésre jutott, hogy a növekedés forrásait számos különböző kapcsolatrendszer kötheti össze.

A pénzügyi kimutatások (számviteli információk) és a pénzügyi teljesítmény összekapcsolásának gondolata az 1950-es évekre nyúlik vissza. A pénzügyi teljesítményt - amelynek mérőszáma lehet akár a jövedelmezőség, a pénztermelő képesség vagy a tőzsdei ár - ekkor még nem nevezték versenyképességnek. Az első úttörő tanulmány Modigliani-Miller [1958] volt, amely bevezette a részvényesi érték fogalmát, amely összekapcsolja a cég értékét és a töke struktúráját (tőkeáttétel, adóvédelem stb.). A következő fontos lépés az volt, amikor Markowitz [1952] felismerte a kockázatok fontosságát, és a kockázatot integrálta a modelljébe. A leggyakoribb elemzési módszer 
a fundamentális elemzés (Ball-Brown [1968]), amely rátaelemzésre épít. A rátaelemzési módszerek a 20. század elejére nyúlnak vissza, de csak a stratégiai gondolkodás fejlődésével, az 1960-as évektől kezdték el széles körben alkalmazni őket (Horrigan [1968]). A 21. században a rátaelemzés használata széles körben elterjedt a vállalatvezetés minden területén, például a teljesítménymenedzsmentben, a vállalati diagnosztikában, a vállalati, partner- és versenytársi értékelésben stb. Chatfield-Vangermeersch [2014] öt iskolát különböztet meg a rátaelemzés területén, jelen cikk módszertana a többváltozós modellező iskolához tartozik. Ennek az iskolának a követői (Bliss [1923], Higgins [1977], Kaplan-Norton [1992] és [1996]) a pénzügyi teljesítmény elemeit vizsgálják, és igyekeznek a pénzügyi és a nem pénzügyi tényezőket integrálni. Általában indikátorrendszert, piramist, összetett indexet vagy kiegyensúlyozott mutatószámrendszer-típusú módszertant használnak. A pénzügyi teljesítmény mérésének másik problémája, hogy a pénzügyi adatok - a vállalat méretét is figyelembe véve - széles tartományban szóródnak (Damodaran [2002]).

Ismert tény (Greenberg és szerzőtársai [1986]), hogy a kettős könyvvitel által kimutatott bevétel, jövedelem (jövedelmezőség) sokkal gyengébb mutatója a pénzügyi teljesítménynek, mint a cash flow. Ez az oka annak, hogy a diszkontált cash flow (discounted cash flow, DCF) módszerek sokkal elterjedtebbek a szabad cash flownál (free cash flow, FCF) a többfázisú értékelési modelleken keresztül (Rappaport [1997]) a diszkontáltosztalék-modellekig (discounted dividend model, DDM) (Bodie és szerzőtársai [2004]). A pénzáramlásokat kétféle módon lehet a kutatási modellekbe integrálni (Damodaran [2002]). Az egyik lehetőség, hogy a beszámoló megfelelö részéből (cash flow kimutatás) közvetlenül nyerjük az információkat, a másik módszer a cash flow közvetett kiszámítása akár az adózott eredményböl, akár az üzemi eredményből [kamatok és nyereségadó-ráfordítások levonása előtti eredmény (earnings before interest and taxes, EBIT)].

A DCF-módszerek legelterjedtebb továbbfejlesztése a gazdasági hozzáadott érték (economic value added, EVA) mutatója (Stewart [1991]). A fö koncepció az, hogy a hangsúly a jövedelmezöségtől a cash flow-n keresztül a vállalat értékteremtésére terelődjön át. Az EVA alkalmazása széles körben elterjedt: alkalmazható a vezetői kifizetések megalapozásától (Fatemi és szerzőtársai [2003]) a stratégiai megvalósítás támogatásáig (Simons [1999]).

A pénzügyiteljesítmény-mérési modellek döntő részét nagy, tőzsdén jegyzett vállalatokra fejlesztették ki (Brem és szerzötársai [2008]). Számos kísérlet történt ezen modelleknek a mikro-, kis- és középvállalati szektorra történő alkalmazására (Garengo és szerzőtársai [2005]), de az eredmények túlságosan változatosak (Neely és szerzötársai [2005]). Csak az EVA, a kiegyensúlyozott mutatószámrendszer (balanced scorecard, BSC) és ezek kombinációja (Bahri és szerzötársai [2011]) tekinthető sikernek.

Számos tényező akadályozza a mikro-, kis- és középvállalatok pénzügyi teljesítményének mérését. E vállalatok nem a nagyvállalatok kisméretü verziói (Penrose [1959]). A kisvállalkozások nagyobb környezeti bizonytalansággal szembesülnek, míg motivációik és cselekedeteik belső konzisztenciája nagyobb (Storey [1994], Welsh-White [1981]). Jellemző rájuk az erőforrások korlátozottsága, valamint a vezetői szakértelem (Garengo és szerzőtársai [2005]) és a teljesítménymenedzsment- 
eszközök viszonylagos hiánya, mindez összetettebb külső környezettel kombinálva (Bahri és szerzőtársai [2011]).

A pénzügyi adatok minősége, átláthatósága és hozzáférhetősége további probléma a mikro-, kis- és középvállalatok esetében (Rauch és szerzőtársai [2009]). Pénzügyi adataik egyik leggyakoribb kritikája az, hogy megbízhatatlanok. Jól példázza ezt, amikor Abouzeedan-Busler [2004] saját teljesítménymérési modelljüket a mikro-, kis- és középvállalatokra adaptálja (11. o.), és - Keasey-Watson [1986], valamint Storey és szerzötársai [1987] munkájára hivatkozva - kijelenti, hogy a mikro-, kis- és középvállalatok pénzügyi adatai nem megbízhatók. Hangsúlyozni kell azonban, hogy a megbízhatóság hiánya és az információs aszimmetria nem szektorspecifikus kérdések, a nagyvállalatokkal kapcsolatban ugyanúgy rendszeresen megjelennek (MillerModigliani [1961]). A témát a banki hitelezés területén vizsgálták a legszélesebb körben (Berger-Udell [2006]), és ezzel kapcsolatban két pontot kell kiemelni: egyrészröl a kritikák ellenére a pénzügyi adatok a hitelképesség értékelésénél továbbra is a szempontok legalább 50 százalékát teszik ki, másrészről a felsorolt források egyike sem érvel konkrét, tényszerü, közvetlen empirikus bizonyítékokkal.

\section{Az adatállomány és a módszertan bemutatása}

\section{A mikro-, kis- és középvállalatok kompetenciáinak mérési módszere}

Empirikus kutatásunk során a KKVVKK-nak a magyar mikro-, kis- és középvállalati versenyképességre vonatkozó primer adatállományát használtuk fel (Szerb és szerzőtársai [2019]). Az adatokat - 2016 és 2020 között együttműködő intézmények és szakosodott szolgáltatók segítségével végrehajtott kérdőívezéssel - kifejezetten abból a célból gyűjtöttük, hogy a mikro-, kis- és középvállalatok vállalati szintű versenyképességét a kompetenciák teljesítményének mérése által lehessen vizsgálni (az adatfelvételt az EFOP-3.6.2-16-2017-00017 támogatta). A felmérések és az adatállományépítés teljes folyamata a KKVVKK szakmai felügyelete mellett történt.

A felmérés menete: a telefonos kapcsolatfelvételt követően személyes találkozásra került sor, amelyen kérdőív kitöltésére kértük fel húsz fö foglalkoztatotti létszám alatt a vállalat egyik operatív működtetésben is részt vevő tulajdonosát, húsz fö foglalkoztatotti létszám felett pedig a vállalat egyik vezető tisztségviselöjét (függetlenül attól, hogy a vállalatban van-e tulajdona). A válaszadók kérdezőbiztos segítségével töltötték ki a kérdöíveket, és szinte kizárólag zárt kérdésekre kellett válaszolniuk. A kérdőív kitöltése során - hasonlóan más vizsgálatokhoz (például Irwin és szerzötársai [1998], Douglas-Ryman [2003], Priem-Butler [2001]) - a válaszadóknak egy ötpontos skálán kellett a felsorolt erőforrások és képességek észlelt fontosságát megítélniük. A felajánlott Likert-típusú skálán az 1 érték egy adott erőforrás és képesség alacsony fontosságát jelölte, míg a 4 érték a kiemelkedően magas relevanciát. A 0 érték azt jelenti, hogy a válaszadó megítélése szerint az adott erőforrás és képesség a vállalat számára egyáltalán nem képvisel stratégiai jelentőséget, miközben a skála fennmaradó pontjai biztosítják a változók fontosságának egységes és fokozatos értékelését és 
számszerűsítését. Az 1-től 4-ig terjedő skála elegendő terjedelmet biztosít a vizsgált változók értékének megkülönböztetéséhez és megitéléséhez (Lederer és szerzötársai [2013]). Összességében a kérdöív alapján 44 darab mikro-, kis- és középvállalat kompetenciateljesítményének mérésére és értékelésére alkalmas változó kvantifikálható. A változók teljes listáját a Függelék F1. táblázata tartalmazza.

A kérdőívet 2013 óta egyre szélesebb körben használják kutatási célokra Magyarországon is és külföldön is, így a potenciálisan félreérthető vagy zavaró kérdéseket már törölték vagy javították. A beérkezett adatokat szigorú eljárásrend szerint ellenőrizték és tisztították. Csak olyan vállalat képezi későbbi elemzések tárgyát, amelynek minden szükséges (versenyképességi és pénzügyi) adata rendelkezésre áll. Kikerültek a mintából az öt fö foglalkoztatotti létszám alatti cégek, valamint azok is, amelyekkel szemben 2020. május 20 -ig csődeljárás, felszámolás, végelszámolás vagy kényszertörlés folyamata kezdődött, zajlott vagy zárult le.

Ez az adattisztítási és -elökészítési folyamat egy $n=1005$-ös mintát eredményezett (az adatállomány dátumbélyege 2020. május 20.). Egy átlagos vállalat 24,9 főt foglalkoztat, és 19,1 év piaci tapasztalattal rendelkezik. A vállalatok 24,6 százaléka a mezögazdaság és az ipar szektoraiban (kivéve építőipar), 12,6 százaléka az építőiparban, 30,0 százaléka a tercier szektoron belül a kereskedelem és gépjármüjavítás ágazataiban, 32,8 százaléka pedig a tercier szektor más szolgáltatási ágazataiban tevékenykedik. Az adatfelvétel különböző éveiben beérkezett részminták között szignifikáns eltéréseket a vállalatok foglalkoztatotti létszáma (méretkategóriája), a vállalatok kora és/vagy ágazati elhelyezkedése alapján nem találtunk.

Ezt követően a Szerb és szerzötársai [2014] és [2019] által kidolgozott hatlépéses módszertan alapján kerültek kiszámításra a változók, az alindexek (pillérek) és a kompozit index (versenyképességi pontérték):

1. a változók azonosítása és az értékek kalkulálása [0;4],

2. a változóértékek normálása a $[0,1]$ tartományba,

3. a pillérértékek kiszámítása az adott pillér alá tartozó, normált változóértékek átlagolásával $[0,1]$,

4. a pillérértékek normálása a $[0,1]$ tartományba,

5. a normált pillérértékek közös átlagra igazítása az értékek azonos, $k$-adik hatványra történő emelésével $[0,1]$,

6. a versenyképességi pontérték kiszámítása a közös átlagra igazított pillérértékek összeadásával $[0,10]$.

A számítás lépéseit a Függelék részletesebben is tartalmazza.

\section{A kutatás koncepcionális modellje és hipotézisei}

A következő koncepcionális modellt fejlesztettük ki (1. ábra). A hosszú távú siker biztosításához a vállalatoknak teljesítményt kell elérniük (Miller-Modigliani [1961], Miller [1986], Kaplan-Norton [1996]). A teljesítményhez megfelelö mennyiségü és minőségű erőforrásra van szükség (Krugman [1994], Porter [1990]). Feltételeztük, 
hogy a vállalat az erőforrás-szemléletben (resource-based view, $R B V$ ) definiált eröforrásokkal rendelkezik (Barney [1991] és [2001]). A vállalat ezeket az erőforrásokat a gazdasági versenyben történő helytállás (a versenyképesség biztosítása) érdekében hasznosítja, tehát fenntartja és fejleszti „versenyképességi teljesítményét”. Ezt a versenyképességet a vállalati szintü kompetenciák teljesítményének mérésére és számszerüsítésére - a Szerb és szerzőtársai [2014] és [2019] által - kidolgozott módszertan felhasználásával kvantifikáljuk.

\section{1. ábra}

A versenyképesség és a pénzügyi teljesítmény összefüggésének koncepcionális modellje

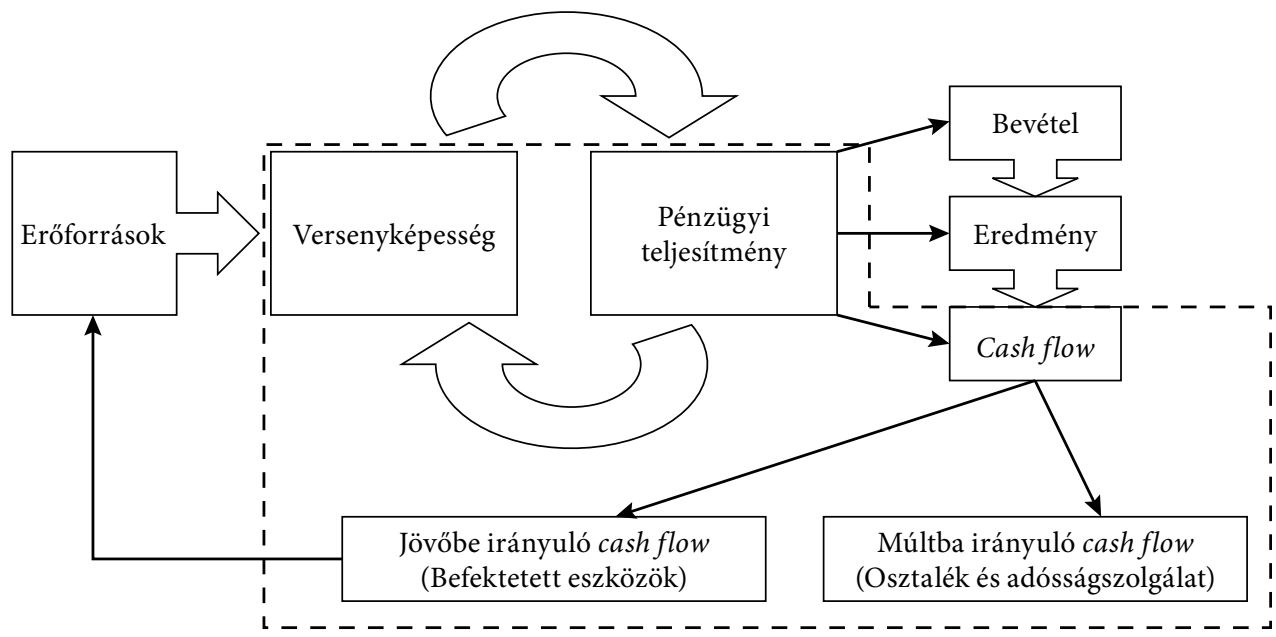

Megjegyzés: a szaggatott vonalak jelen tanulmány tárgyát jelölik ki.

Forrás: saját szerkesztés.

A versenyben történő sikeres helytállás egyik egyértelmü bizonyítéka a magas pénzügyi teljesítmény (Chatfield-Vangermeersch [2014]). A versenyképesség és a pénzügyi teljesítmény között kétirányú kapcsolatot feltételeztünk (Kaplan-Norton [1996], Bahri és szerzőtársai [2011]), ezzel az okozati összefüggések polémiájában nem foglalunk állást. A pénzügyi teljesítményt a generált cash flow segítségével értelmeztük (Greenberg és szerzötársai [1986]), bár a bemutatott szakirodalom alapján számos más alternatív megoldás is elképzelhetö.

A hivatkozott szakirodalommal ellentétben ez a tanulmány azt vizsgálja, hogy a vállalatok mire fordítják a hasznot, és nem azt, hogy hogyan érték el. Emiatt kell megkülönböztetni a múltba és a jövőbe irányuló cash flow-kat. A múltba irányuló cash flow-t a vállalkozási tevékenység érdekében megszerzett eröforrások költségeire költik, ezek az adósságok és az osztalékok. Az adósságszolgálat további két összetevőből áll: a tőketörlesztésböl és a kamatból. A szerzők a ,jövőbe irányuló cash flow” kifejezésen a generált cash flow jövőbeli fejlesztések érdekében történő hasznosítását értik. Az állóeszköz-beruházást (capital expenditure, CAPEX) az ingatlanokban, gépekben és berendezésekben bekövetkező változással mérik, míg az innovációs változó az immateriális beruházásokra összpontosít. 
Ebben a tanulmányban versenyképességet a pénzügyi teljesítményt, azaz a cash flow-t generáló képességen keresztül mérik. Ha a vállalat képes pénzügyi teljesítményt elérni, akkor biztosan versenyképes is (Stewart [1991], Rappaport [1997]). Ebből az összefüggésből származik az 1. HIPOTÉZIsÜNK.

1. HIPOTÉZIs: a pénzügyi teljesítmény pozitív összefüggésben áll a versenyképességgel.

Koncepcionális modellünk alapján megfogalmazható az a várakozás, hogy a jövőbe irányuló cash flow-nak fontos szerepe van a versenyzői kompetenciák teljesítményének fenntartásában és fejlesztésében, mert hozzájárul az erőforrások és képességek mennyiségének és/vagy minőségének növeléséhez (Barney [2001]). Másik oldalról a források kivonása csökkenti a pénzügyi erőforrások mennyiségét, így a múltba irányuló cash flow valószínüleg hátráltatja a vállalat versenyképességét (Miller-Modigliani [1961], Barney [2001]). A koncepcionális modell alapján definiált két cash flow-orientáció (a múltba és a jövőbe irányuló) nem zárja ki egymást: egy mikro-, kis- vagy középvállalat vezetői dönthetnek úgy, hogy ugyanabban a pénzügyi évben mindkét irányba pénzt költsenek (például új tartós eszközöket is vásárolnak és osztalékot is fizetnek).

1.a HIPOTÉzIs: a jövőbe irányuló cash flow pozitív összefüggésben áll a versenyképességgel.

1.b HIPOTÉZIs: a múltba irányuló cash flow negatív összefüggésben áll a versenyképességgel.

Nincs bizonyíték arra, hogy a pénzügyi teljesítmény (cash flow) komponenseinek a versenyképesség szempontjából azonos lenne a jelentőségük (Chatfield-Vangermeersch [2014]). A versenyképesség definíciója és a bemutatott irodalom alapján egyaránt az a várakozás fogalmazható meg, hogy a versenyzői kompetenciák teljesítménye (Belderbos és szerzőtársai [2013], Halilem és szerzőtársai [2014]) szempontjából a vállalati innováció (Schumpeter [1976], Vossen [1998], Arslanagic-Kalajdzic és szerzötársai [2017]) kiemelt jelentőségü. A leírtak alapján a 2. HIPOTÉZIs a következő.

2. HIPOTÉZIs: a cash flow minden (jelen tanulmány keretében vizsgált) komponense közül az innovációval kapcsolatos cash flow versenyképességre gyakorolt hatása a legerősebb.

Az eddig kijelölt vizsgálati szempontot ki kell még egészíteni a pénzügyi teljesítményhez (cash flow-hoz) kapcsolódó kockázatok (a volatilitás) elemzésével (Rappaport [1997], Damodaran [2002]). A versenyképesség fogalma kétségkívül sokkal inkább szól a hosszú távú teljesítményről, mint a rövid távú sikerekről (Porter [1990], Chikán [2008]). A kiegyensúlyozott pénzügyi teljesítményt felmutató vállalatok valószínűbb, hogy képesek versenyelőnyt elérni, fenntartani és fejleszteni. A leírtakból - ceteris paribus - következik az, hogy a kockázatok (a volatilitás) negatív összefüggésben állnak a versenyképességgel, méghozzá a pénzügyi teljesítmény bármely szintje mellett. Ez a vélt összefüggés vezetett a 3. HIPOTÉzIs megfogalmazásához. 
3. нIPOтÉzIs: a cash flow kockázata (volatilitása) negatív összefüggésben áll a versenyképességgel.

\section{Az adatok bemutatása}

Tanulmányunk empirikus elemzéseihez két adatállományt kombináltunk. Az egyik a KKVVKK magyar mikro-, kis- és középvállalati versenyképesség 2020. május 20-i dátumbélyegü adatállománya (Szerb és szerzőtársai [2014] és [2019]). A másik az előbbi adatállományban szereplö vállalatok nyilvános pénzügyi-számviteli adatait tartalmazza a 2014-2018 közötti ötéves időszakra. Az 1. ábrán bemutatott koncepcionális modellben látható változókat a vizsgálatok operacionalizálása érdekében a 2. ábra szerint dekomponáltuk.

\section{2. ábra}

A változók dekomponálása

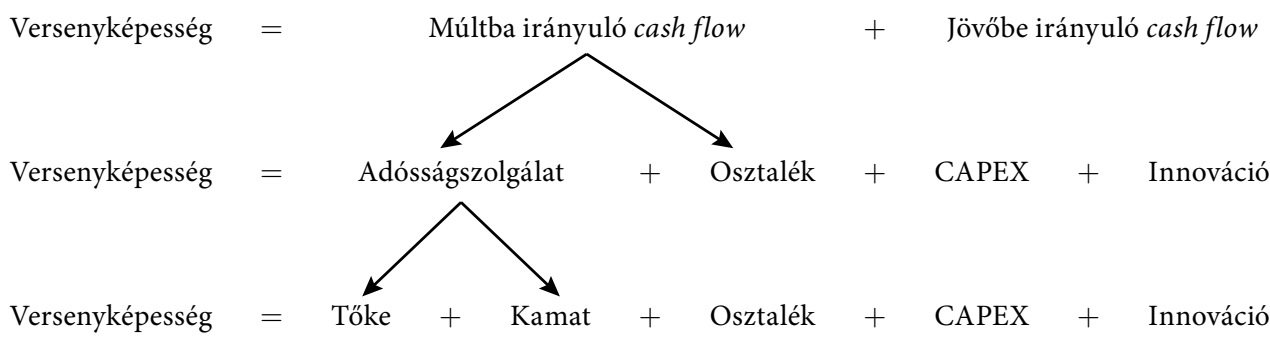

Forrás: saját szerkesztés.

A kötelezettségek, a kamatfizetés, az osztalékok, az állóeszköz-beruházás (CAPEX) és az innovációs változók számszerüsítésére a Függelék F2. táblázatában látható módon került sor. A pénzügyi helyzetet az adott változók „szintje” (átlaga) és volatilitása (szórása) írja le. Az értékek széles tartománya átskálázást is indokolt, amit mérlegböl származó adatok (mint például a kötelezettségek vagy a CAPEX) esetén az összes eszköz segítségével lehetett megtenni (Rappaport [1997], Damodaran [2002]). Az eredménykimutatásból származó adatok (mint például a kamatfizetés vagy az osztalék) esetén ugyanerre a célra számos alternatív megoldás alkalmazható, ezek közül egyik sem tekinthető általánosan elfogadottnak és széles körben alkalmazottnak. Egyik lehetőség az átskálázásra az eredménykimutatásból származó adatok természetes alapú logaritmusának kiszámítása. Másik lehetőség a normálással történő átskálázás a $[0,1]$ tartományba, ahogyan azt a versenyképességi adatoknál is alkalmaztuk. (Ehhez az egyes évek adatait átlagoltuk, majd a nagyságrendi különbségek kiszürésére az értékeket az adott sor maximumával osztottuk.)

Az innovációs változó kalkulálása eltért a beszámolóból származó többi pénzügyi adat esetén bemutatottaktól. A K + F-ráfordítások ugyanis nem részei a mikro-, kis- és középvállalatok beszámolóinak, még a kiegészítő mellékletben sem feltétlenül található erröl információ. E ponton kombinálnunk kellett 
a versenyképességi felmérésből és az eredménykimutatásból származó adatokat. A kérdöív tartalmazott egy kérdést az elmúlt három év K + F-ráfordításairól (ezer forintban), valamint az új/továbbfejlesztett termékek/szolgáltatások árbevételen belüli arányáról (kategória) is. Ezeket a válaszokat az innovációs cash flow becslése érdekében kombináltuk az eredménykimutatásból származó értékesítés nettó árbevételével (ezer forintban).

Az innovációs változó bemutatott számszerüsítési megoldása tautológiát okoz, mert az új/továbbfejlesztett termékek/szolgáltatások árbevételen belüli aránya (T3 változó, lásd Függelék F1. táblázat) egyike a versenyképesség (termék)pillére alá rendezett változóknak. A probléma megoldása érdekében a T3 változó kihagyásával újraszámoltuk a versenyképességi indexet. ${ }^{1}$ Lényeges hangsúlyozni, hogy ezzel nem a változó mikro-, kis- és középvállalati versenyképességben betöltött szerepének és jelentőségének a megkérdőjelezése a cél, hanem a magyarázó és magyarázott változók számszaki összefüggésének megszüntetése. Az átalakítás a versenyképesség más - az innovációhoz közvetetten vagy közvetlenül kapcsolódó - változóját nem érintette.

A független változók alapvető, leíró statisztikai eszközökkel történő jellemzése látható az 1. táblázatban.

\section{1. táblázat}

Leíró statisztikai jellemzés $(n=1005)$

\begin{tabular}{lrrrrc}
\hline & Átlag & Medián & Szórás & Minimum & Maximum \\
\hline KOT_ATL_N & 0,029 & 0,009 & 0,069 & 0,000 & 1,000 \\
KAMAT_ATL_N & 0,015 & 0,003 & 0,057 & 0,000 & 1,000 \\
OSZTALEK_ATL_N & 0,024 & 0,001 & 0,076 & 0,000 & 1,000 \\
CAPEX_ATL_N & 0,032 & 0,005 & 0,105 & $-0,398$ & 1,000 \\
INNOV_A_N & 0,018 & 0,000 & 0,074 & 0,000 & 1,000 \\
KOT_ARM_ATL & 0,439 & 0,416 & 0,216 & 0,020 & 1,000 \\
KOT_ARM_V & 0,017 & 0,007 & 0,027 & 0,000 & 0,180 \\
KAMAT_ATL_LN & 5,690 & 6,315 & 2,815 & 0,000 & 12,150 \\
KAMAT_V_LN & 11,278 & 12,212 & 5,427 & 0,000 & 25,910 \\
OSZTALEK_ATL_LN & 4,924 & 6,464 & 4,531 & 0,000 & 13,220 \\
OSZTALEK_V_LN & 10,145 & 13,930 & 9,203 & 0,000 & 26,620 \\
CAPEX_ARM_ATL & 0,061 & 0,024 & 0,113 & $-0,120$ & 0,670 \\
CAPEX_ARM_V & 0,037 & 0,005 & 0,099 & 0,000 & 0,710 \\
\hline
\end{tabular}

Forrás: saját szerkesztés.

A 2. táblázatban a változók Pearson-féle lineáris korrelációs kapcsolatai láthatók.

\footnotetext{
${ }^{1} \mathrm{Az}$ eredeti (T3 változóval) és az átszámolt (T3 nélküli) versenyképességi pontértékek közötti Pearson-féle lineáris korrelációs együttható értéke: 0,999 (kétoldali szignifikancia =0,000).
} 
2. táblázat

Korrelációs mátrix $(n=1005)$

\begin{tabular}{lcccccc}
\hline & VINDEX & $\begin{array}{c}\text { KOT_ } \\
\text { ATL_N }\end{array}$ & $\begin{array}{c}\text { KAMAT_ } \\
\text { ATL_N }\end{array}$ & $\begin{array}{c}\text { OSZTALEK_ } \\
\text { ATL_N }\end{array}$ & $\begin{array}{c}\text { CAPEX_ } \\
\text { ATL_N }\end{array}$ & $\begin{array}{c}\text { INNOV_N } \\
\text { A_N }\end{array}$ \\
\hline VINDEX & 1 & $0,265^{* *}$ & $0,154^{* *}$ & $0,221^{* *}$ & $0,182^{* *}$ & $0,288^{* *}$ \\
KOT_ATL_N & & 1 & $0,448^{* *}$ & $0,490^{* *}$ & $0,454^{* *}$ & $0,295^{* *}$ \\
KAMAT_ATL_N & & & 1 & $0,184^{* *}$ & $0,253^{* *}$ & $0,163^{* *}$ \\
OSZTALEK_ATL_N & & & & 1 & $0,081^{* *}$ & $0,222^{* *}$ \\
CAPEX_ATL_N & & & & & 1 & $0,206^{* *}$ \\
\hline
\end{tabular}

${ }^{* *} 0,01$ szinten, ${ }^{\star} 0,05$ szinten szignifikáns korrelációs együtthatók.

Forrás: saját szerkesztés.

A változók között kivétel nélkül szignifikáns, azonos irányú, nincs/gyenge ( 0,5 alatti) erösségü kapcsolat állapítható meg.

\section{Eredmények}

Empirikus vizsgálatunkban a legkisebb négyzetes (OLS) és a binomiális logisztikus regressziós elemzést használtuk, mindkét esetben enter és backward módszerekkel. $\mathrm{Az}$ enter módszer az összes független változót beilleszti a modellbe, míg a backward módszer elöször az összes változót a modellbe helyezi, majd ezt követően a legrosszabb statisztikájú változókat kezdi eltávolítani. A folyamatnak akkor van vége, ha az összes fennmaradó változó szignifikáns hatással van a függő változóra.

Kutatásunk a koncepcionális modellen belül az 1. ábrának a szaggatott vonal által határolt részére koncentrál. A legkisebb négyzetes regresszió eredményeit a 3. táblá$z a t$ foglalja össze, amelyben a függő változó a versenyképességi index, míg a független változók $[0,1]$-es skálán mért normalizált változók.

Az eredmények alapján az adósságszolgálat két eleme közül a tőketörlesztés bizonyult szignifikánsnak ( $p=0,022$ és $p=0,004)$, míg a kamatfizetés nem $(p=0,268)$. Ennek minden bizonnyal az az oka, hogy a folyamatos kamatfizetés képessége a hitelhez jutás minimális feltétele, a hitel nyújtója elsősorban a töketörlesztés képességét vizsgálja a hitelbírálat során. A versenyképesebb vállalkozások nagyobb eséllyel jutnak ilyen forrásokhoz, amelyek törlesztése is markánsabban jelenik meg a pénzügyi beszámolóikban. Ehhez képest az a tény, hogy a hitelek kamatait is képesek kigazdálkodni, a versenyképesség megítélése szempontjából már nem hordoz többletinformációt.

Egyébként a változókhoz tartozó koefficiensek mind az elözetesen várt irányba mutatnak: a tőketörlesztés $(p=0,004 ; \beta=0,111)$, az osztalékfizetés $(p=0,001 ; \beta=0,113)$, az állóeszköz-beruházás ( $p=0,021 ; \beta=0,078)$ és az innováció $(p=0,000 ; \beta=0,214)$ koefficiensei pozitívak, ami azt mutatja, hogy amennyiben az adott vállalkozás többet költ az adott tevékenységre, akkor az átlagosan várhatóan nagyobb versenyképességet is ér 
3. táblázat

A legkisebb négyzetes regresszió eredményei $(n=1005)$

\begin{tabular}{lcc}
\hline & 1. modell (enter) & 2. modell (backward) \\
\hline KOT_ATL_N & $0,095^{* *}$ & $0,111^{* * *}$ \\
KAMAT_ATL_N & $(0,022)$ & $(0,004)$ \\
OSZTALEK_ATL_N & 0,037 & \\
& $(0,268)$ & \\
CAPEX_ATL_N & $0,115^{* * *}$ & $0,113^{* * *}$ \\
& $(0,01)$ & $(0,001)$ \\
INNOV_A_N & $0,076^{* *}$ & $0,078^{* *}$ \\
& $(0,025)$ & $(0,021)$ \\
F-próba & $0,212^{* * *}$ & $0,214^{* * *}$ \\
Korrigált $R^{2}$ & $(0,000)$ & $(0,000)$ \\
ANOVA & 30,193 & 37,426 \\
Durbin-Watson-próba & 0,127 & 0,127 \\
VIF átlag (min-max) & 0,000 & 0,000 \\
& 1,821 & 1,820 \\
\hline
\end{tabular}

Megjegyzés: a cellákban a standardizált koefficiensek $(\beta)$, míg a zárójelben a szignifikanciaértékük szerepel.

*** 1 százalékos, ${ }^{\star *} 5$ százalékos, ${ }^{\star} 10$ százalékos szinten szignifikáns.

Forrás: saját szerkesztés.

el. Mindkét modellben az innovációs változónak van a legnagyobb hatása $(\beta=0,212$, illetve $\beta=0,214$ ), ami igazodik az irodalomáttekintésben vázoltakhoz. Az osztalékfizetésnek és a töketörlesztésnek közel azonos, míg az állóeszköz-beruházásnak gyengébb a hatása a vállalkozás versenyképességére.

Érdemes észrevenni a negatív koefficiensek hiányát is, ami azt jelenti, hogy vizsgálatunkban nincs olyan cash flow elem, amelynek növelése a versenyképesség várható csökkenését idézné elö. Mind a koncepcionális modell, mind a hipotézisek azt az előzetes véleményt sugallták, hogy a versenyképesség növelésében elsősorban a jövőbe irányuló cash flow-kra támaszkodhat a vállalkozás, míg a múltba irányuló cash flow-k - azáltal, hogy a vállalkozás pénzügyi forrásokat veszít - csökkentik a versenyképességet. Ezzel szemben az itt bemutatott eredmények azt mutatják, hogy ha a vállalkozás képes a múltba irányuló cash flow igények kielégítésére is, akkor az is a nagyobb versenyképesség jele.

A gondolatmeneten továbbhaladva, a hangsúly eddig a pénzügyi teljesítményen (cash flow) volt, miközben ennek a teljesítménynek a volatilitását (kockázatát) nem vizsgáltuk. Ehhez első lépésben a versenyképességi mutatót három egyenlő számosságú csoportra osztottuk, és a legjobb versenyképességü csoportot összehasonlítottuk a legrosszabb versenyképességű csoporttal binomiális logisztikus regresszió felhasználásával. Ennek során mind az enter, mind a backward módszert felhasználtuk - ahogy 
a korábbi modellekben is. A független változók a megadott pénzügyi adatok szintje (átlaggal mérve) és kockázata (a variancia alapján mérve). A nagyságrendi eltérések kiküszöbölése a mérlegtételeknél a mérlegföösszeggel történő elosztással, míg az eredménykimutatáshoz kapcsolódó tételek esetében a természetes alapú logaritmus alkalmazásával volt lehetséges. (A változók listája a Függelék F2. táblázatában látható.)

\section{4. táblázat}

A binomiális logisztikus regresszió eredményei $(n=670)$

\begin{tabular}{lccc}
\hline & $\begin{array}{c}\text { 3. modell } \\
(\text { enter })\end{array}$ & $\begin{array}{c}4 . \text { a modell } \\
(\text { backward })\end{array}$ & $\begin{array}{c}4 . b \text { modell } \\
(\text { backward })\end{array}$ \\
\hline KOT_ARM_ATL & 1,320 & & \\
KOT_ARM_V & $(0,532)$ & & \\
OSZTALEK_ATL_LN & 0,067 & & $1,116^{* * *}$ \\
& $(0,423)$ & & $(0,000)$ \\
OSZTALEK_V_LN & 1,495 & $1,118^{* * *}$ & \\
CAPEX_ARM_ATL & $(0,138)$ & $(0,000)$ & \\
CAPEX_ARM_V & 0,868 & & \\
INNOv_A_N & $(0,290)$ & & \\
& $15,903^{* *}$ & $16,160^{* *}$ & $(0,021)$ \\
$\chi^{2}$-próba & $(0,022)$ & $0,057^{* *}$ & $(0,000)$ \\
Nagelkerke-féle $R^{2}$ & $0,067^{* *}$ & $(0,031)$ & 205,673 \\
Hosmer-Lemeshow-próba & $(0,041)$ & $1,265^{* * *}$ & 0,352 \\
Helyesen besorolt esetek (százalék) & $1,266^{* * *}$ & $(0,000)$ & 0,110 \\
ROC görbe alatti terület & $(0,000)$ & 211,802 & 73,0 \\
\hline
\end{tabular}

Megjegyzés: a cellákban az $\operatorname{Exp}(B)$ koefficiensek, zárójelben a szignifikanciaértékük szerepel.

${ }^{* * *} 1$ százalékos, ${ }^{* *} 5$ százalékos, ${ }^{\star} 10$ százalékos szinten szignifikáns.

Forrás: saját szerkesztés.

A 3. modellben a 2. modellben már szignifikáns kapcsolatot mutató változókat vizsgáltuk tovább (4. táblázat). Az első eredmény, hogy ha figyelembe vesszük az adott pénzügyi teljesítménymutató szintjét (átlag) és kockázatosságát (variancia) is, akkor sem a tőketörlesztés $(p=0,423)$ varianciája, sem az osztalékfizetés $(p=0,290)$ varianciája esetében nincs szignifikáns kapcsolat. Ezt a későbbiekben a backward módszer igazolja, hiszen ezen varianciaváltozók elhagyásával jobban illeszkedö modelleket kapunk.

A 4.a modell a backward módszer segítségével letisztultabb képet ad (4. táblázat). Azt már a 2. modell alapján beláttuk, hogy az adósságszolgálaton belül csak a töketörlesztés változójának lehet szignifikáns hatása a versenyképességre, a 4. modell alapján viszont 
már azt is látjuk, hogy ha a legjobb, illetve a legrosszabb versenyképességű vállalkozásokat hasonlítjuk össze, akkor a tőketörlesztés hatása sem szignifikáns.

Külön figyelmet érdemel az állóeszköz-beruházás változója. 5 százalékos szignifikanciaszinten az állóeszköz-beruházás szintje (átlag) nagyon magas értéket vesz fel $(\beta=16,160)$, ugyanennek az értéknek a varianciája viszont nagyon alacsony $(\beta=0,057)$. Ez arra utal, hogy a legjobb versenyképességü vállalkozásokat a legrosszabbaktól nagyban megkülönbözteti az, hogy mennyire képesek állóeszközberuházásokat indítani. Ha képesek rá, az nagyon nagy mértékben (több mint 16-szorosan) növeli annak esélyét, hogy a vállalkozás a legjobb versenyképességi pontokat érje el. Ennek azonban nagymértékben ellene hat a beruházások varianciája. Tehát az előbb leírt összefüggés csak abban az esetben fog érvényesülni, ha a vállalkozás a beruházásait nem alkalmanként és/vagy eseti jelleggel indítja, hanem kiegyensúlyozottan, egy hosszú távú pályát leírva.

$\mathrm{Az}$ állóeszközre vonatkozó változók esetében egy matematikai összefüggésre is érdemes figyelmet fordítani. Az átlag változójának koefficiense 16,160, míg a variancia változójának koefficiense 0,057 , és az előbbi változó koefficiensének reciproka $(1 / 16,160=0,061)$ közelíti az utóbbi változó koeffiensét, a 0,057-et, tehát a modell egészében ez a két változó hatása kiegyenlíti egymást. Ez az eredmény indokolta a $4 . b$ modell megalkotását (4. táblázat).

A $4 . b$ modell abban különbözik a $4 . a$ modelltől, hogy a két, állóeszközre vonatkozó változó már nem képezi a magyarázó változók részét. A $4 . b$ modell jelentősen letisztultabb, mint a 4.a modell, miközben a két modell statisztikai lényegét tekintve megegyezik. Eszerint csak a fizetett osztalék szintje (átlag) $(p=0,000, \beta=1,116)$ és az innovációs változó ( $p=0000, \beta=1,264)$ gyakorol szignifikáns hatást az eredményváltozóra. Ha ez a két adat ismert, úgy a modell az esetek 73,0 százalékában helyesen állapítja meg azt, hogy a vállalkozás melyik versenyképességi kategóriába tartozik.

\section{Konklúzió}

A bemutatott eredmények (különösen a 2 . modell és a $4 . b$ modell) alapján a hipotézisek tesztelhetők. Az 1. нIротÉZIs a cash flow generálási képességre, az 1.a HIPOTÉzIS a jövőre, az 1.b нIротÉzIs pedig a múltra irányuló cash flow-ra összpontosított. A modellek azt mutatják, hogy a nagyobb cash flow nagyobb versenyképességet jelez, így az 1. ніротÉZIs elfogadható. Részletesebben vizsgálva az is megállapítható, hogy a jövőbe és a múltba irányuló cash flow-k is jelentős pozitív hatással vannak a versenyképességre. Ez alapján az 1.a HIPOTÉZIs elfogadása, míg az 1.b HIPOTÉZIs elvetése indokolt. Mindkét modellben az összes jelentős cash flow elem pozitív hatással van a versenyképességre (a 2 . modellben minden együttható pozitív, míg a $4 . b$ modellben minden együttható nagyobb, mint 1). Meg kell jegyezni, hogy a cash flow elemek nem egyformán befolyásolják a versenyképességet, mivel a jövőbe irányuló cash flow elemek magyarázó ereje sokkal magasabb, mint a múltba irányulóké.

A 2. HIPOTÉZIs csak az innovációval kapcsolatos cash flow-ra összpontosít. $\mathrm{Az}$ innovációs változó magyarázó ereje minden modellben a legnagyobb, tehát 
a hipotézis elfogadható. Kétségkívül az innovációnak önmagában is lényeges szerepe van a versenyképesség alakulásában, de a többi változó bevezetése jelentős mértékben növeli a modellek magyarázó erejét.

A 3. ніроте́zis a cash flow-k kockázatára (volatilitására) koncentrál. Az eredmények alapján elmondható, hogy a vállalkozások cash flow-t generáló képessége a lényeges, míg a cash flow volatilitása (kockázata) nem, így a hipotézis elvetése indokolt. Az állóeszköz-beruházások esetében (jövőbe irányuló cash flow) az eredmények ellentmondásosak. Eszerint, ha a vállalkozás képes állóeszköz-beruházásokat indítani, akkor ez nagymértékben növelheti a versenyképességét, de csak abban az esetben, ha beruházásait kiegyensúlyozottan, egy hosszú távú pályát leírva indítja. Másrészröl, osztalékok esetén (múltba irányuló cash flow) az a következtetés fogalmazható meg, hogy a versenyképesebb vállalkozások vélhetően elöször a költségszerkezetükbe építik be a tulajdonosok elvárt megtérülését, és csak ha a vállalkozás pénzügyi helyzete elég stabil, abban az esetben vonják ki a pénzügyi forrásokat hoszszú távú tervek alapján. Hangsúlyozni kell, hogy mindkét következtetés a jelenlegi módszertanon alapul, és további elemzésekre van szükség.

A tanulmány leglényegesebb nóvuma a mikro-, kis- és középvállalatok vállalati szintü kompetenciáinak teljesítménye (versenyképessége) és pénzügyi teljesítménye közötti összefüggés feltárása. A szakirodalommal - amely döntően azzal foglalkozik, hogy a mikro-, kis- és középvállalatok hogyan érik el a versenyképességet és/ vagy a pénzügyi teljesítményt - ellentétben ebben a kutatásban bizonyítékok találhatók arra vonatkozóan, hogy a mikro-, kis- és középvállalatok hogyan használják fel pénzügyi teljesítményüket annak érdekében, hogy fenntarthassák és növelhessék versenyképességüket.

Az eredmények elsősorban a kutatók számára relevánsak. Amikor a versenyképességet a vállalati szintü képességek teljesítménye alapján mérik, akkor a pénzügyi teljesítményt nem veszik figyelembe, mivel a pénzügyi adatok (és/vagy mutatók) nem eredményezik a teljesítményt, hanem a már elért teljesítményt mérik. A teljesítményt okozó és a teljesítményt reprezentáló tényezők közötti kapcsolat így homályban marad, ezért szükséges az ismereteket a jelen tanulmányban is megjelenő empirikus eredményekkel bővíteni. Az eredmények hozzájárulnak a meglévő irodalomhoz, és új kutatási irányokat is nyithatnak, mivel jelzik, hogy az innovációval és az állóeszközökbe történő beruházással kapcsolatos pénzügyi adatok (funkcionális területek szerint) részletes vizsgálata indokolt. Ezzel szemben a tőkeszerkezet, különösen a kölcsöntőke hatása nehezen igazolható.

Az eredmények a vállalati szakemberek számára a pénzügyi döntések meghozatala szempontjából is relevánsak. Egyrészt hangsúlyozzák az innovációs kiadások fontosságát, másrészt egyértelmüsítik, hogy a versenyképes vállalkozások nemcsak a tartós eszközökbe fektetnek, hanem eközben a tulajdonosok jólétére is forrásokat (osztalékot) allokálnak. A versenyképes vállalkozások tulajdonosai csak akkor vonják ki a nyereséget, ha a vállalkozás pénzügyi helyzete elég stabil, és ezt koncepciózusan, hosszú távú tervek alapján teszik.

A szakpolitika és a társadalom számára az eredmények csak közvetettek. Az eredmények azt mutatják, hogy a beruházás (mind tárgyi, mind immateriális javak 
esetében) lényeges tényező a versenyképesség támogatása szempontjából. A gazdaságfejlesztési támogatásoknak (például beruházásösztönzés), valamint a számviteli és adózási szabályoknak (például értékcsökkenési leírás) támogatniuk kellene ezeket a befektetéseket, különösen akkor, ha valamilyen következetes, hosszú távú folyamat részeként valósulnak meg. A versenyképesség és a pénzügyi teljesítmény közötti kapcsolat vizsgálatával közelebb kerülünk a hosszú távú siker összetevőinek megértéséhez is, ez végső soron hozzájárul a munkahelyek megőrzéséhez.

Igazoltnak tekinthető tehát az a vállalati szakemberek és tanácsadóik által régen vallott állítás, hogy az innovációt elősegítő befektetett erőforrások hozzájárulnak a versenyképesség és ezáltal a pénzügyi teljesítmény fokozásához. Az azonban már további kutatásokat igényel, hogy a vállalatoknak mikor mibe és hogyan lenne érdemes invesztálniuk ahhoz, hogy a konjunkturális időszakok után is tartósabb garanciájuk legyen a versenyképességük folyamatos megújítására és a pénzügyi eredményük növelésére.

Az eredmények hasznosíthatóságának és kiterjeszthetőségének korlátot szab az, hogy nincs bizonyíték a két teljesítménytípus (versenyképességi és pénzügyi) pontos oksági viszonyairól. Tanulmányunkban pénzügyi teljesítménnyel magyaráztuk a versenyképességet. További korlátot jelent az is, hogy bár a mintaelemszám a jelenlegi irodalomhoz képest nagynak tekinthetö, mégis a minta nem reprezentatív, és a mintabontások (például iparági, térbeli stb.), valamint a részmintás elemzések lehetősége is korlátozott. A pénzügyi adatok is csak korlátozottan álltak rendelkezésre, ez különösen a költségszerkezet pontos ismeretének hiánya miatt jelent korlátot.

A jövőbeli kutatások során szükséges kibővíteni a pénzügyi és a versenyképességi adatállományokat is, elsősorban hosszabb idősorok és/vagy paneladatok és -modellek létrehozása céljából. A kutatás nemzetközivé tétele, több ország és több mikro-, kis- és középvállalat bevonása is jelentősen növelné az elemzési lehetőségek tárházát. A jövőbeli kutatás további szempontjai a részminták részletesebb elemzései szektoronként, ellátási lánconként, klaszterenként, térben és további lényeges keresztváltozó szerint vizsgálva. Ezenkívül a jelenlegi üzleti tendenciák (például nemzetközivé válás, digitalizálás stb.) beépítése és a vállalat funkcionális területeinek tételes vizsgálatai is segíthetik az összkép árnyalását.

\section{Hivatkozások}

Abouzeedan, A.-Busler, M. [2004]: Typology analysis of performance models of small and medium-size enterprises (SMEs). Journal of International Entrepreneurship, Vol. 2. No. 1-2. 155-177. o. https://doi.org/10.1023/b:jien.0000026911.03396.2d.

Acs, Z. J. [2011]: High-impact firms: gazelles revisited. Megjelent: Fritsch, M. (szerk.): Handbook of Research on Entrepreneurship and Regional Development: National and Regional Perspectives. Edward Elgar Publishing, Cheltenham, 133-174. o. https://doi.org/10.4337/ 9780857936493.00010.

Aragón-Sánchez, A.-SÁnchez-Marín, G. [2005]: Strategic orientation, management characteristics, and performance. A study of Spanish SMEs. Journal of Small Business Management, Vol. 43. No. 3. 287-308. o. https://doi.org/10.1111/j.1540-627x.2005.00138.x. 
Arslanagic-Kalajdzic, M.-Balboni, B.-Kadic-Maglajlic, S.-Bortoluzzi, G. [2017]: Product innovation capability, export scope and export experience. Quadratic and moderating effects in firms from developing countries. European Business Review, Vol. 29. No. 6. 680-696. o. https://doi.org/10.1108/ebr-12-2015-0180.

Atkinson, K. E. [1989]: An introduction to numerical analysis. 2nd ed. John Wiley \& Sons, New York.

BAhri, M.-St-Pierre, J.-SAKKA, O. [2011]: Economic value added: a useful tool for SME performance management. International Journal of Productivity and Performance Management, Vol. 60. No. 6. 603-621. o. https://doi.org/10.1108/17410401111150779.

BALL, R.-Brown, P. [1968]: An empirical evaluation of accounting income numbers? Journal of Accounting Research, Vol. 6. No. 2. 159-178. o. https://doi.org/10.2307/2490232.

BARnEY, J. B. [1991]: Firm resources and sustained competitive advantage. Journal of Management, Vol. 17. No. 1. 99-120. o. https://doi.org/10.1177/014920639101700108.

BARNEY, J. B. [2001]: Resource-based theories of competitive advantage: A ten-year retrospective on the resource-based view. Journal of Management, Vol. 27. No. 6. 643-650. o. https:// doi.org/10.1177/014920630102700602.

Belderbos, R. A.-Leten, B.-Suzuki, S. [2013]: How global is R\&D? Firm-level determinants of home country bias in R\&D. Journal of International Business Studies, Vol. 44. No. 8. 765-786. o. https://doi.org/10.1057/jibs.2013.33.

Berger, A. N.-Udell, G. F. [1998]: The economics of small business finance: The roles of private equity and debt markets in the financial growth cycle. Journal of Banking and Finance, Vol. 22. No. 6/8. 613-673. o. https://doi.org/10.1016/s0378-4266(98)00038-7.

Berger, A. N.-Udell, G. F. [2006]: A more complete conceptual framework for SME finance. Journal of Banking and Finance, Vol. 30. No. 11. 2945-2966. o. https://doi.org/10.1016/j. jbankfin.2006.05.008.

BLIss, J. H. [1923]: Financial and operating ratios in management. The Ronald Press Company, New York.

Bodie, Z.-Kane, A.-Marcus, A. J. [2004]: Essentials of Investments. McGraw Hill, New York.

Brem, A.-Kreusel, N.-Neusser, C. [2008]: Performance measurement in SMEs: literature review and results from a German case study. International Journal of Globalization and Small Business, Vol. 2. No. 4. 411-427. o. https://doi.org/10.1504/ijgsb.2008.018102.

BRIstow, G. [2010]: Critical reflections on regional competitiveness: Theory, policy, practice. Routledge, London, https://doi.org/10.4324/9780203865408.

Buckley, P. J.-PAss, C. L.-Prescott, K. [1988]: Measures of International Competitiveness: A critical Survey. Journal of Marketing Management, Vol. 4. No. 2. 175-200. o. https://doi. org/10.1080/0267257x.1988.9964068.

Chatfield, M.-Vangermeersch, R. [2014]: The History of Accounting (RLE Accounting): An International Encyclopedia. Routledge, London, https://doi.org/10.4324/9781315883489. Chikán Attila [2008]: National and firm competitiveness: a general research model. Competitiveness Review, Vol. 18. No. 1-2. 20-28. o. https://doi.org/10.1108/10595420810874583. Damodaran, A. [2002]: Investment valuation. 2. kiadás. John Wiley \& Sons, New York.

Delgado, M.-Ketels, C.-Porter, M. E.-Stern, S. [2012]: The determinants of national competitiveness. National Bureau of Economic Research, Cambridge, MA. https://doi. org/10.3386/w18249.

Dholakia, R. R.-Kshetri, N. [2004]: Factors impacting the adoption of the internet among SMEs. Small Business Economics, Vol. 23. No. 4. 311-322. o. https://doi.org/10.1023/ b:sbej.0000032036.90353.1f. 
Douglas, T. J.-Ryman, J. A. [2003]: Understanding competitive advantage in the general hospital industry: evaluating strategic competencies. Strategic Management Journal, Vol. 24. No. 4. 333-347. o. https://doi.org/10.1002/smj.301.

Fatemi, A.-Desai, A. S.-Katz, J. P. [2003]: Wealth Creation and Managerial Pay: MVA and EVA as Determinants of Executive Compensation. Global Finance Journal, Vol. 14. No. 2. 159-179. o. https://doi.org/10.1016/s1044-0283(03)00010-3.

Filippetti, A.-Frenz, M.-Ietto-Gillies, G. [2011]: Are innovation and internationalization related? An analysis of European countries. Industry and Innovation, Vol. 18. No. 5. 437-459. o. https://doi.org/10.1080/13662716.2011.583461.

Filippetti, A.-Frenz, M.-IEtTo-Gillies, G. [2017]: The Impact of Internationalization on Innovation at Countries' Level: The Role of Absorptive Capacity. Cambridge Journal of Economics, Vol. 41. No. 2. 413-439. o. https://doi.org/10.1093/cje/bew032.

Garengo, P.-Biazzo, S.-Bititci, U. S. [2005]: Performance measurement systems in SMEs: A review for a research agenda. International Journal of Management Reviews, Vol. 7. No. 1. 25-47. o. https://doi.org/10.1111/j.1468-2370.2005.00105.x.

GRANT, R. M. [1991]: Toward the resource-based theory of competitive advantage: Implications for strategy formulation. California Management Review, Vol. 33. No. 3. 114-135. o. https://doi.org/10.2307/41166664.

Grant, R. M. [2016]: Contemporary Strategy Analysis. 9. kiadás, John Wiley \& Sons, Chicester.

Greenberg, R. R.-Johnson, G. L.-RAmesh, K. [1986]: Earnings versus cash flow as a predictor of future cash flow measures. Journal of Accounting, Auditing and Finance, Vol. 1. No. 4. 266-277. o. https://doi.org/10.1177/0148558x8600100402.

Halilem, N.-Amara, N.-LAndry, R. [2014]: Exploring the Relationships between Innovation and Internationalization of Small and Medium-Sized Enterprises: A Nonrecursive Structural Equation Model. Canadian Journal of Administrative Sciences, Vol. 31. No. 1. 18-34. o. https://doi.org/10.1002/cjas.1272.

Henrekson, M.-Johansson, D. [2010]: Gazelles as job creators: a survey and interpretation of the evidence. Small Business Economics, Vol. 35. No. 2. 227-244. o. https://doi. org/10.1007/s11187-009-9172-z.

Higgins, R. C. [1977]: How much growth can a firm afford? Financial Management, Vol. 6. No. 3. 7-16. o. https://doi.org/10.2307/3665251.

Horrigan, J. O. [1968]: A short history of financial ratio analysis. The Accounting Review, Vol. 43. No. 2. 284-294. o.

Huggins, R.-Thompson, P. [2013]: UK Competitiveness Index 2013. Cardiff University, Cardiff.

Irwin, J. G.-Hoffman, J. J.-LAmont, B. T. [1998]: The effect of the acquisition of technological innovations on organizational performance: a resource-based view. Journal of Engineering and Technology Management, Vol. 15. No. 1. 25-54. o. https://doi.org/10.1016/ s0923-4748(97)00028-3.

Jensen, M. C.-Meckling, W. H. [1976]: Theory of the Firm: Managerial Behavior, Agency Costs and Ownership Structure. Journal of Financial Economics, Vol. 3. No. 4. 305-360. o. https://doi.org/10.1016/0304-405x(76)90026-x.

Kaplan, R. S.-Norton, D. P. [1992]: The balanced scorecard, measures that drive performance. Harvard Business Review, Vol. 70. No. 1. 71-79. o.

KAPLAN, R. S.-NoRTON, D. P. [1996]: The balanced scorecard: translating strategy into action. Harvard Business Press, Boston. 
KeAsEy, K.-Watson, R. [1986]: The prediction of small company failure: some behavioural evidence for the UK. Accounting and Business Research, Vol. 17. No. 65. 49-57. o. https:// doi.org/10.1080/00014788.1986.9729781.

Krugman, P. [1994]: Competitiveness: a dangerous obsession. Foreign Affairs, Vol. 73. No. 2. 28-44. o. https://doi.org/10.2307/20045917.

LALL, S. [2001]: Competitiveness indices and developing countries: an economic evaluation of the global competitiveness report. World Development, Vol. 29. No. 9. 1501-1525. o. https:// doi.org/10.1016/s0305-750x(01)00051-1.

Lederer, M.-Schott, P.-Huber, S.-Kurz, M. [2013]: Strategic Business Process Analysis: A Procedure Model to Align Business Strategy with Business Process Analysis Methods. Megjelent: Fischer, H.-Schneeberger, J. (szerk.): International Conference on SubjectOriented Business Process Management. Springer, Berlin-Heidelberg, 247-263. o. https:// doi.org/10.1007/978-3-642-36754-0_16.

LEE, J.-KARPOVA, E. [2018]: Revisiting the competitiveness theory in the new global environment: review and analysis of the competitiveness definition. International Journal of Competitiveness, Vol. 1. No. 3. 189-205. o. https://doi.org/10.1504/ijc.2018.091474.

LENGNICK-HALL, C. A. [1992]: Innovation and competitive advantage: What we know and what we need to learn. Journal of Management, Vol. 18. No. 2. 399-429. o. https://doi. org/10.1177/014920639201800209.

Man, T. W. Y.-LAU, T.-ChAN, K. F. [2002]: The competitiveness of small and Medium enterprises. A conceptualization with focus on entrepreneurial competencies. Journal of Business Venturing, Vol. 17. No. 2. 123-142. o. https://doi.org/10.1016/s0883-9026(00)00058-6.

Markowitz, H. M. [1952]: Portfolio Selection. The Journal of Finance, Vol. 7. No. 1. 77-91. o. https://doi.org/10.2307/2975974.

McGahan, A. M. [1999]: Competition, Strategy and Business Performance. California Management Review, Vol. 41. No. 3. 74-101. o. https://doi.org/10.2307/41165998.

Miller, D. [1986]: Configurations of Strategy and Structure: Towards a Synthesis. Strategic Management Journal, Vol. 7. No. 3. 233-249. o. https://doi.org/10.1002/smj.4250070305.

Miller, D.-Whitney, J. O. [1999]: Beyond Strategy: Configuration as a Pillar of Competitive Advantage. Business Horizons, Vol. 42. No. 3. 5-17. o. https://doi.org/10.1016/s00076813(99)80016-0.

Miller, M. H.-Modigliani, F. [1961]: Dividend policy, growth, and the valuation of shares. The Journal of Business, Vol. 34. No. 4. 411-433. o. https://doi.org/10.1086/294442. Magyarul: Osztalékpolitika, növekedés és a részvények árfolyama. Megjelent: Modigliani, F.: Pénz, megtakarítás, stabilizáció. Közgazdasági és Jogi Könyvkiadó, Budapest, 1988, 287-319. o.

Modigliani, F.-Miller, M. H. [1958]: The Cost of Capital, Corporation Finance and the Theory of Investment. American Economic Review, Vol. 48. No. 3. 261-297. o. Magyarul: A tőke költsége, vállalati pénzügyek és a beruházás elmélete. Megjelent: Modigliani, F.: Pénz, megtakarítás, stabilizáció. Közgazdasági és Jogi Könyvkiadó, Budapest, 1988, 231-271. o.

Myers, S. C.-Majluf, N. S. [1984]: Corporate financing and investment decisions when firms have information that investors do not have. Journal of Financial Economics, Vol. 13. No. 2. 187-221. o. https://doi.org/10.1016/0304-405x(84)90023-0.

Neely, A. D.-Gregory, M.-Platts, K. [2005]: Performance measurement system design: a literature review and research agenda. International Journal of Operations and Production Management, Vol. 15. No. 4. 80-116. o. https://doi.org/10.1108/01443579510083622.

Nоотевоом, B. [1994]: Innovation and diffusion in small firms: theory and evidence. Small Business Economics, Vol. 6. No. 5. 327-347. o. https://doi.org/10.1007/bf01065137. 
Penrose, E. T. [1959]: The Theory of the Growth of the Firm. Basil Blackwell, Oxford. https:// doi.org/10.1093/0198289774.001.0001.

Peteraf, M. A. [1993]: The cornerstones of competitive advantage: A resource-based view. Strategic Management Journal, Vol. 14. No. 3. 179-191. o. https://doi.org/10.1002/ smj.4250140303.

Porter, M. E. [1990]: The competitive advantage of nations. Harvard Business Review, Vol. 68. No. 2. 73-93. o.

Porter, M. E. [1998]: Cluster and the new economics of competition. Harvard Business Review, Vol. 76. No. 6. 77-90. o.

Priem, R. L.-Butler, J. E. [2001]: Is the resource-based 'view' a useful perspective for strategic management research? Academy of Management Review, Vol. 26. No. 1. 22-40. o. https://doi.org/10.5465/amr.2001.4011928.

RAPpApORT, A. [1997]: Creating Shareholder Value. A Guide for Managers and Investors. Free Press, New York.

Rauch, A.-Wiklund, J.-Lumpkin, G. T.-Frese, M. [2009]: Entrepreneurial orientation and business performance: An assessment of past research and suggestions for the future. Entrepreneurship Theory and Practice, Vol. 33. No. 3. 761-787. o. https://doi.org/10.1111/ j.1540-6520.2009.00308.x.

Ray, G.-BArney, J. B.-Muhanna, W. A. [2004]: Capabilities, business processes, and competitive advantage: choosing the dependent variable in empirical tests of the resource-based view. Strategic Management Journal, Vol. 25. No. 1.23-37. o. https://doi.org/10.1002/smj.366.

Schumpeter, J. A. [1976]: Capitalism, Socialism and Democracy. Routledge, London. https:// doi.org/10.4324/9780203202050.

SChumpeter, J. A. [1980]: A gazdasági fejlődés elmélete. Közgazdasági és Jogi Könyvkiadó, Budapest.

Simons, R. S. [1999]: Performance Measurements and Control Systems for Implementing Strategy. Prentice Hall, New York.

Singh, R. K.-GARG, S. K.-DeshmukH, S. G. [2007]: Interpretive structural modelling of factors for improving competitiveness of SMEs. International Journal of Productivity and Quality Management, Vol. 2. No. 4. 423-440. o. https://doi.org/10.1504/ijpqm.2007.013336.

Stewart, G. [1991]: The Quest for Value: A Guide for Senior Managers. HarperCollins, New York.

SтоJсіс, N. [2012]: Theoretical Foundations and Measurement of Competitiveness. Business Excellence, Vol. 6. No. 2. 143-166. o.

Storey, D. J. [1994]: Understanding the Small Business Sector. Routledge, London.

Storey, D. J.-Keasey, K.-Wynarczy K, P.-Watson, R. [1987]: The Performance of Small Firms. Croom-Helm Ltd., London.

Szerb LÁszló-Csapi Vivien-Deutsch Nikolett-Hornyák Miklós-Horváth ÁdÁmKruZslicz FerenC-LÁnyi Beatrix-Márkus Gábor-Rácz GábOR-RapPai Gábor-Rideg ANDRÁs-SzÜCs KRISZTIÁN-ULBERT JózSEF [2014]: Mennyire versenyképesek a magyar kisvállalatok? A magyar kisvállalatok (MKKV szektor) versenyképességének egyéni-vállalati szintű mérése és komplex vizsgálata. Marketing and Management, 48. évf. ksz. 3-21. o.

Szerb LÁszló-Rideg András-Kruzslicz Ferenc-Márkus GÁbor-Lukovszki LíviaKrabatné Fehér Zsófia-Hornyák Miklós-Horváth Krisztina [2019]: Kompetenciaalapú versenyképesség-mérés és -elemzés a magyar kisvállalati (mKKV) szektorban. RIERC kutatási beszámoló, 2019/001. PTE-KTK Regionális Innováció- és Vállalkozáskutatási Központ, Pécs, https://doi.org/10.13140/RG.2.2.29806.77124. 
VeCSENyi JÁnos [2011]: Kisvállalkozások indítása és működtetése. 4. kiadás, 72h.com MEEXO, Budapest, https://doi.org/10.1556/9789634542254.

Vossen, R. W. [1998]: Relative strengths and weaknesses of small firms in innovation. International Small Business Journal, Vol. 16. No. 3. 88-94. o. https://doi.org/10.1177/ 0266242698163005.

WACH, K. [2014]: The Theoretical Modelling of the Firm-Level International Competitiveness in Business Studies. Megjelent: Kiendl-Wendner, D.-Wach, K. (szerk.): International Competitiveness in Visegrad Countries: Macro and Micro Perspectives. Fachhochschule Joanneum, Graz, 101-124. o.

WANG, H. [2014]: Theories for competitive advantage. Megjelent: Hasan, H. (szerk.): Being Practical with Theory. A Window into Business Research. lulu.com, Raleigh, NC, 33-43. o. Welsh, J. A.-White, J. F. [1981]: A small business is not a little big business. Harvard Business Review, Vol. 59. No. 4. 18-27. o.

Wernerfelt, B. [1984]: A Resource-Based View of the Firm. Strategic Management Journal, Vol. 5. No. 2. 171-180. o. https://doi.org/10.1002/smj.4250050207.

\section{Függelék}

A kompetenciaalapú mikro-, kis- és középvállalati versenyképesség számításának hatlépéses módszertana ${ }^{2}$

1. Az indikátorok azonosítása, A változók Kalkulálása. Az indikátorok kiszűrése a felmérés egyéb adatai közül, változókká konvertálás és az összetett változók kiszámítása.

2. A változóK NORMÁlásA. A változóértékek normálása a $[0,1]$ tartományba az (F1) összefüggés alapján:

$q_{i, p}=\frac{s_{i, p}}{\max s_{i, p}}, \quad$ minden $\quad p=1 \ldots t$,

ahol:

$q_{i, p}$ az $i$-edik vállalat $p$ változójának a normált pontértéke,

$s_{i, p}$ az $i$-edik vállalat $p$ változójának az eredeti értéke,

maxs $s_{i, p}$ a $p$ változó maximális értéke.

3. A PILLÉREK KALKulálásA. A pillérértékek az adott pillér alá tartozó normált változóértékek átlagolásával jöttek létre. A j-edik pillér esetében az (F2) összefüggés szerint:

$z_{i, j}=\frac{\sum_{1}^{v} q_{i, p}}{v}$

ahol:

$v$ az adott pillér változóinak száma,

$z_{i, j}$ az $i$-edik vállalat $j$-edik pillérének az eredeti pillérértéke.

${ }^{2}$ Szerb és szerzőtársai [2019] 35-37. o. alapján. 
4. A PILlÉRÉRTÉKEK NORMÁLÁSA. A pillérértékek normálása a $[0,1]$ tartományba az (F3) összefüggés alapján:

$x_{i, j}=\frac{z_{i, j}}{\max z_{i, j}}, \quad$ minden $\quad j=1 \ldots 10, \quad$ a pillérek száma,

ahol:

$x_{i, j}$ az $i$-edik vállalat $j$-edik pillérének a normált pontértéke,

$z_{i, j}$ az $i$-edik vállalat $j$-edik pillérének az eredeti pillérértéke, $\max z_{i, j}$ a j-edik pillér maximális értéke.

5. A NORMÁlt PILlÉRÉRTÉKEK KÖzÖs ÁTLAgRA IgAzÍTÁsa. A tíz pillér normált értékeinek átlaga jelentős eltérést mutat. Ez azt jelenti, hogy jelentős különbségek vannak az egyes pillérek javításához szükséges erőforrások terén. Az alacsonyabb átlagú pilléreket nehezebb, a magasabb átlagúakat könnyebb javítani. Ez egyben azt is jelenti, hogy a javításukhoz szükséges pótlólagos erőforrások különböznek. Mivel a kutatások célja az volt, hogy az eredmények a vállalatok stratégiai terveinek kidolgozásához is alkalmazhatók legyenek, ezért az eltérö átlagokból eredő torzításokat korrigálni kellett, hogy a marginális hatásokat legalább a pillérek átlagán kiegyenlítsék. Ehhez egy olyan transzformáció szükséges, amely lehetővé teszi a tíz pillér átlagának kiegyenlítését. Elöször is kiszámítottuk a tíz pillér átlagának az átlagát:

$\bar{x}=\frac{\sum_{i=1}^{n} x_{i}}{n}$.

A következő művelet révén az $x_{i, j}$-értékeket úgy transzformáltuk, hogy a $[0,1]$-es tartományban maradjanak. Egy lehetséges, több szempontból is alkalmas módszer az eredeti értékek azonos, $k$-adik hatványra emelése, amellyel tulajdonképpen valamennyi megfigyelést önmagával súlyozzuk:

$y_{i, j}=x_{i, j}^{k}$.

A feladat annak a - nem feltétlenül egész - $k$-értéknek megtalálása, amely az (F6) egyenlet megoldását adja:

$\sum_{i=1}^{n} x_{i, j}^{k}-n \bar{y}_{j}=0$.

A megoldás Newton-Raphson-módszerrel (Atkinson [1989]) történik a 0 érték kezdeti feltételezése mellett. A $k$ kikalkulálása után a számolás egyszerü. Megjegyzésre érdemes, hogy

$\bar{x}_{j}<\bar{y}_{j}, k<1$,

$\bar{x}_{j}=\bar{y}_{j}, k=1$,

$\bar{x}_{j}>\bar{y}_{j}, k>1$,

ahol $k$ az igazítás nagyságaként és irányaként értelmezhető.

6. A VERSENYKÉPESSÉGI PONTOK KALKULÁLÁSA. Végül minden vállalat versenyképességi pontja a tíz pillér összeadásával számítható az (F7) szerint: 
Versenyképességi index: $i_{i}=\sum_{j=1}^{m} y_{i, j} \quad$ kiszámítása minden $i$-re,

ahol:

$i=1,2, \ldots, n$, ahol $n$ a vállalatok száma,

$j=1,2, \ldots, m$, ahol $m$ a pillérek száma.

\section{Táblázatok}

F1. táblázat

A KKVVKK versenyképesség-változóinak teljes listája

\begin{tabular}{ll}
\hline Kód & Leírás \\
\hline H2 & Az alkalmazottakkal kapcsolatban felmerült problémák \\
H3 & A továbbképzésen részt vett foglalkoztatottak aránya \\
H4 & Ösztönzési rendszerek alkalmazása \\
H5 & Az emberi tỏke egyedisége \\
\hline T1 & Termékinnováció \\
T2 & Termék/szolgáltatás bevezetésével vagy javításával kapcsolatos tevékenységek \\
T3 & Az innovatív termékek eladásának az értékesítés nettó árbevételén belüli aránya \\
T4 & Termék, szolgáltatás egyedisége és a folyamatos innováció \\
\hline HP1 & A vállalkozás értékesítésének földrajzi területei Magyarországon \\
HP2 & A cég piaci versenyének jellemző szintje \\
HP3 & Célpiac várható alakulása a következő öt évben \\
HP4 & Versenyintenzitás \\
HP5 & Gyors reagálás a vevői igényekre \\
\hline
\end{tabular}

E1 Gazdasági és innovációs együttmüködések száma

E2 Együttműködések idejének aránya a cégalapítás óta eltelt időhöz képest

E3 A fejlődést elősegítő külső segítség mértéke

E4 Partnerkapcsolatok, hálózatosodás egyedisége

TERME1 A vállalkozás technológiájának szintje magyarországi viszonylatban

TERME2 Az alkalmazott technológia érettsége/kora és technológiai innováció

TERME3 Környezeti menedzsment és minőségbiztosítás

TERME4 IKT-eszközök alkalmazása

TERME5 Technológia, termelésirányítás, minőségbiztosítás és IKT-eszközök egyedisége

D1 Az információforrások alkalmazása/figyelembevétele a döntéshozatal során

D2 A pénzügyi információk alkalmazása/figyelembevétele a döntéshozatal során

D3 Információmegosztás

D4 Konzultáció a döntéshozatal során

D5 A szervezet működtetése, adminisztratív rutinok, tudásmegosztás 
Az F1. táblázat folytatása

\begin{tabular}{ll}
\hline Kód & Leírás \\
\hline S1 & A vállalkozás jellemző stratégiai iránya \\
S2 & Növekedési stratégia (az üzletágak száma és kapcsolódása alapján) \\
S3 & A válaszadó vezető vállalkozói képességei \\
S4 & A hosszú távú proaktív stratégia egyedisége \\
\hline M1 & A termékek/szolgáltatások egyedisége \\
M2 & A legfontosabb termék/szolgáltatás árszínvonala \\
M3 & Az értékesítési csatornák szofisztikáltsága \\
M4 & Alkalmazott marketingkommunikációs eszközök \\
M5 & Marketinginnováció \\
M6 & A marketingmódszerek egyedisége \\
\hline N1 & A külföldi vevők összes vevőn belüli aránya \\
N2 & Az exportárbevétel aránya az értékesítés teljes nettó árbevételén belül \\
N3 & Nyelvismeret, nyelvi képességek \\
N4 & Az elhelyezkedés egyedisége \\
\hline O1-2 & WebIndex 1.0 (online jelenlét sebessége, komplexitása, megjelenése) \\
O3 & WebIndex 2.0 (Mail, Apple, GPlus, Facebook, Twitter, Instagram) \\
O4 & Az online marketingmegoldások alkalmazása \\
\hline
\end{tabular}

Forrás: Szerb és szerzőtársai [2019]. 


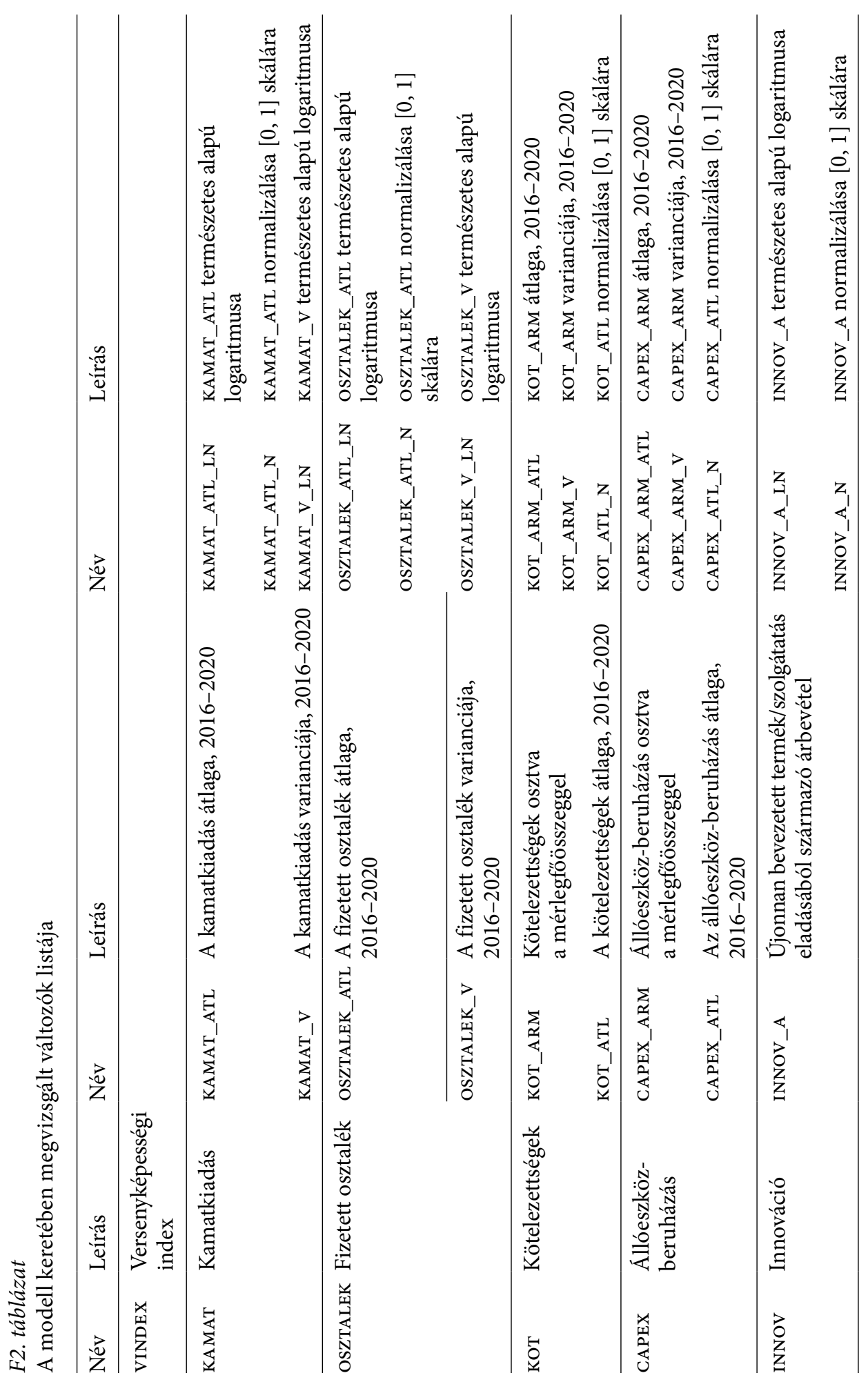

